\title{
IMPORTANCE AND IMPACT OF FOREIGN INVESTMENT ON THE ECONOMIC DEVELOPMENT OF BOSNIA AND HERZEGOVINA
}

\author{
Milan Šušić \\ University of Business Studies Banja Luka, Faculty of Business and Financial Studies, \\ Bosnia and Herzegovina
}

date of paper receipt:

19.03.2018.

Review article date of sending to review:

23.03.2018. date of review receipt:

05.04.2018.

\section{SUMMARY}

From the perspective of macroeconomic indicators, investment is a significant determinant of economic development as a whole, as well as the development of economic entities in the micro segment. Investments present an essential element of any economic policy, as their presence provides a platform, not only for economic development, but also create a basic condition for the stability of economic and social trends. Foreign direct investment plays an important role in the financing of the global economy, and the most common presenting the most important tool in financing the national economies of developing countries and countries in transition. Demand for foreign investment in the global market is large and therefore the states are directing significant activities in order to create a more favorable environment to attract investors. The paper pays special attention to direct investmens in financing the economy on a global scale, their importance for the development of the global economy and particulary screens the impact of foreign direct investment in the economic development of Bosnia and Herzegovina. The emphasis is placed on activities that have to be carried out in order to realize more investments. With the use of statistical and quantitative analysis, the paper shows that the inflow of foreign capital is fundamental prerequisite for generating and accelarating of economic development in general. The inflow of foreign capital has an exstraodinary positive impact on the economic development and increase of business activities in visably undeveloped and slow economic in Bosnia and Herzegovina.

Keywords: foreign investment, the global economy, economic development, knowledge and technology

\section{INTRODUCTION}

Foreign Investment (FI-Foreign Investment) is a form of investment in which foreign investor keeps the ownership rights, provides the control and management of the firm in which they invested the funds, in order to achieve long-term interests. These investments are the most important instrument of foreign capital inflow because they represent a direct inflow from abroad, i.e. direct inflow of the capital in the economic system of the host country.

Foreign investment, as a form of international capital mobility, represents an important contributor to more efficient activities in the economy and It provides faster exit to the international market. Evaluation of investment efficiency is the basis for making investment decisions from one country to another, which will consequently lead to improvement of the economy. Foreign investment is 
the key development factor in the modern economy, and jointly with the trade, represents the most important leverage of an enterprise, organization of production, supplying goods and services on a global scale.

Foreign investment support the companies in organizing production on a global scale, providing an efficient supply of raw materials, energy, labor as the input, and facilitate the placement of products and services as the output in the most important markets in a profitable way. On the basis of such activities, the companies can use its advantages in technology, expertise, and economies of scale. Developing countries having high state debt and unfavorable economic situation show huge interest in gaining as higher foreign investment as possible. It has been especially important after bank loans and various financial aid ceased to arrive in some countries. Countries in transition, aiming to integrate into the world economic system, can overcome negative economic tendencies with the help of international capital inflow.

Developed countries, faced with a financial crisis, have been also interested in an increased inflow of foreign capital, since the foreign investment is the most important element of development strategies in general.

It is not just the capital that comes with foreign direct investment from one country to another, but also the investment package containing new technologies, managerial skills and new markets. In addition, bearing higher risks, FDI is significantly increasing the opportunities for making profits. Foreign direct investment is autonomous transaction of long-term capital movements, motivated by economic interests with the profit at the first place.

Observing today's economic systems at the global market, we can notice that the economic systems, in order to accelerate their economic development compete to each other, aiming to attract foreign capital. In fact, the most significant competition is seen in the area of "greenfield" investments. It is important to elaborate, how and why are the countries competing for foreign direct investment, and on the other hand, why the other countries are the main investors of this type of investment. In order to monitor investments, the following core analytic indicators related to foreign direct investment are examined: (1) Flows of foreign direct investment (FDI), which represents new investments during the observed period (usually one year period). They represent the position of the current account. Total flows are divided by instruments used for investment, and are as follows: owners capital (ownership in subsidiaries), and shares in subsidiaries and affiliated companies, reinvested earnings as part of retained earnings of investors that is not distributed; others investment of FDI, like the borrowing and lending of funds, including various financial instruments and trade credits between investing company and company which has capital inflow; (2) Stocks of foreign direct investment represent the value of investments at the end of monitored period. In balance sheets, the foreign direct investment is in the assets side and in the liabilities side if the investment is coming from the host country FDI stocks are divided into: equity capital and reinvested earnings; (3) Income of foreign direct investment is income summarized by direct investors during the period. It is divided into three categories: (a) dividends earned in the reporting period and the profits allocated to direct investor without deduction of income tax; (b) reinvested earnings; (c) interest on loans, i.e. interest earned on loans to subsidiaries, without deduction of income tax.

In addition, an important indicator is intensity of foreign direct investment, measured as a percentage of gross domestic product (the ratio of the average internal and external flows of foreign direct investment and GDP). Higher intensity indicator means more foreign investment in relation to the size of the economy.

One of the goals of this paper is to demonstrate that in developing countries acceleration of the economic development can be achieved with the use of instruments of foreign capital, and with the additional capital inflow from abroad. The purpose of foreign capital should be the achievement of higher investment rates, higher rates of national income, acceleration of economic development in comparison to the development which would be achieved by using only domestic capital.

The second objective of the research is, that different instruments of foreign capital inflow have 
different impacts on the macro-economic categories in global circumstances. In the paper the impact of FDI on economic development in BH economy has been analyzed. Also, the impact on: employment growth, budget revenues and export volume has been monitored. Foreign investment can cause negative effects on domestic companies, if foreign investors squeeze domestic producers from the market, and become monopolists. The damage may be made also to the payment balance of the host country due to the high outflow of investors' profits or because of large imports of inputs.

\section{FOREIGN INVESTMENT AND EFFECTS OF ECONOMIC DEVELOPMENT}

The role and importance of foreign direct investment for the national economy (Todaro M P \& Smit S C 2006) was primarily in improving the key macroeconomic indicators. FDI is efficient form of usage of private savings in the process of funding economic development and in reducing the gap between the planned investment and the local savings. Secondly, it is significant contribution of foreign direct investment in overcoming the gap of foreign trade of host country. Thus, the foreign investment is efficiently covering discrepancy between planned revenues and taxes collected, and the expenditures volume in the budget. FDI is useful because it contributes to transfer of managerial and entrepreneurial experiences. Finally, FDI today represents the main channel for the transfer of new technology among countries.

Foreign direct investment can bring many advantages for foreign investors (Jovanovic \& Gavrilovic P 2006) among which, the most important are: savings in transport costs (both, inputs and finished products), lower labor costs, available infrastructure, savings in customs costs and contribution on imported goods, closer position to the customers, the possibility of quick and efficient delivery with availability of information about preferences and possibility for fast adoption of products in accordance with market requirements.

In particular, it is necessary to analyze the relationship between investment and economic growth. This interdependence can be seen by measurement of macroeconomic aggregates, i.e. in growth rate, movement of investment, foreign exchange level and trends and other. Changes are related to economic developments at the national level, on the basis of which it is possible to assess the success of development policy. When the positive elements are on increase, there are positive structural changes. In periods of crises the negative changes are strengthening (slowing the growth and investment, increasing unemployment rate, increasing in deficits, etc.) (P Samuelson \& Nordhaus W 1992) investments generate significant positive effects on the economy of the host country. Their impact is recorded in two points: the quantitative growth, measured by the balance and the total inflow measured by gross domestic product, exports and domestic investment: and qualitative through the transfer to the host country the investment, trade, technology and financial flows. To determine the effects of FDI on economic growth of the host country is not an easy task. There are a large number of variables, where the effects are associated with specifics of each country, sectors of the economy and investment. Variables can be viewed from two aspects: first, they are supplementing domestic factors of production and creating the conditions for new employment, and secondly they stimulate the development of the host country through technology transfer, manpower training, liaising with the local economy, and in enabling better presence of local companies at the world market.

The effects of FDI depend on the stage of economic development of the country, and these stages are divided in four phases (Dunning J 1982). In the first phase of development, the most important role is played by natural resources, and at this stage, no significant effects to the host country economy are visible. If the country has an economic development at the second phase, it will record an increase in domestic investment, while investing in public goods, communications and transport is present. The state in this phase, shifts its interest from natural resources to the production of labor-intensive goods, and the effects depend on the infrastructure and macroeconomic policy. The third phase covers the period when the development of innovation, knowledge management, 
organizational benefits, rationalization of production and investments are supported. All these variables have the effects on strengthening the competitiveness of local companies and appearance on new markets. The fourth stage is the highest stage of economic development and in this stage a lot of post-industrial service companies have been recorded. The products are direct services and cross-border connections and effects are becoming more intense in this phase. Effects of foreign direct investment on the economic development of the host country depend on strategy which the country has chosen: import substituting strategy or export developing strategy. Studies have shown that investments are extremely important for economic growth of host country, where we want to examine: Does the inflow of foreign direct investment increase or decrease the total investment volume in the host country?

If foreign direct investment enters into the sector in which there is competition from domestic companies, there is a competitive struggle whose consequences might be the delaying in investment and exit of certain domestic companies from the sector. This will lead to reduction of the total investment in the sector and thus in the entire economy. If the FDI enters the new sector (primary, secondary, tertiary) then the total investment in the country will be increased.

\section{FOREIGN INVESTMENTS IN THE COUNTRIES OF THE EUROPEAN UNION}

Total investments in the EU amounted slightly less than one-fifth (below 20\%) of gross domestic product. The investment rate ( $\mathrm{I} / \mathrm{Y}$ ) is stable in a long-term. The rate of investment in more developed EU countries is lower and ranges up to one sixth, while in the new Member States and less developed ones investment rate reaches up to one quarter of the output (Popović G 2009 ).

Table 1 shows gross domestic product at market prices in millions of national currencies for EU Member States and candidate countries for EU membership (Eurostat, March 2, 2018) and Table 2. Real GDP growth in the EU, 2006-2016 ( \% of changes compared to the previous year,\% per year) (Eurostat, 2017) 
Table 1 Gross domestic product at market prices; Current prices, million units of national currency (GDP and main aggregates - selected international annual data. Last update: 02/03/18; Source of data: Eurostat)

\begin{tabular}{|c|c|c|c|c|c|c|c|}
\hline 1 Time & 2010 & 2011 & 2012 & 2013 & 2014 & 2015 & 2016 \\
\hline EU ( 28 countries $)$ & $12,827,959.8$ & $13,200,971.1$ & $13,463,405.2$ & $13,577,271.0$ & $14,044,690.5$ & $14,797,443.8$ & $14,907,852.2$ \\
\hline Euro area (19 countries) & $9,547,583.5$ & $9,799,884.1$ & $9,837,425.9$ & $9,934,799.5$ & $10,157,598.4$ & $10,515,138.9$ & $10,788,818.3$ \\
\hline Belgium & $365,100.5$ & $379,106.3$ & $387,500.1$ & $392,339.8$ & $400,288.2$ & $410,435.2$ & $423,048.4$ \\
\hline Bulgaria & $74,771.3$ & $80,759.0$ & $82,040.4$ & $82,166.1$ & $83,634.3$ & $88,571.3$ & $94,129.9$ \\
\hline Czech Republic & $3,962,464.0$ & $4,033,755.0$ & $4,059,912.0$ & $4,098,128.0$ & $4,313,789.0$ & $4,595,783.0$ & $4,773,240.0$ \\
\hline Denmark & $1,810,926.0$ & $1,846,854.0$ & $1,895,002.0$ & $1,929,677.0$ & $1,981,165.0$ & $2,027,108.0$ & $2,065,962.0$ \\
\hline Germany & $2,580,060.0$ & $2,703,120.0$ & $2,758,260.0$ & $2,826,240.0$ & $2,932,470.0$ & $3,043,650.0$ & $3,144,050.0$ \\
\hline Estonia & $14,716.5$ & $16,667.6$ & $17,934.9$ & $18,932.3$ & $19,766.3$ & $20,347.7$ & $21,098.3$ \\
\hline Ireland & $167,583.2$ & $171,939.2$ & $175,561.1$ & $180,298.3$ & $194,537.2$ & $262,037.4$ & $275,567.1$ \\
\hline Greece & $226,031.4$ & $207,028.9$ & $191,203.9$ & $180,654.3$ & $178,656.5$ & $176,312.0$ & $174,199.3$ \\
\hline Spain & $1,080,935.0$ & $1,070,449.0$ & $1,039,815.0$ & $1,025,693.0$ & $1,037,820.0$ & $1,079,998.0$ & $1,118,522.0$ \\
\hline France & $1,998,481.0$ & $2,059,284.0$ & $2,086,929.0$ & $2,115,256.0$ & $2,147,609.0$ & $2,194,243.0$ & $2,228,857.0$ \\
\hline Croatia & $328,942.8$ & $333,325.9$ & $330,925.1$ & $331,374.4$ & $331,266.4$ & $338,975.0$ & $349,410.4$ \\
\hline Italy & $1,604,514.5$ & $1,637,462.9$ & $1,613,265.0$ & $1,604,599.1$ & $1,621,827.2$ & $1,652,622.3$ & $1,680,948.1$ \\
\hline Cyprus & $19,299.5$ & $19,731.0$ & $19,489.7$ & $18,140.5$ & $17,605.9$ & $17,742.0$ & $18,122.5$ \\
\hline Latvia & $17,937.9$ & $20,302.8$ & $21,885.6$ & $22,831.5$ & $23,681.5$ & $24,353.1$ & $24,926.7$ \\
\hline Lithuania & $28,027.7$ & $31,275.3$ & $33,348.5$ & $34,959.6$ & $36,568.3$ & $37,426.6$ & $38,668.3$ \\
\hline Luxembourg & $40,177.8$ & $43,164.6$ & $44,112.1$ & $46,499.6$ & $49,993.0$ & $52,101.9$ & $53,004.8$ \\
\hline Hungary & $27,224,599.0$ & $28,304,938.0$ & $28,781,064.0$ & $30,247,077.0$ & $32,591,713.0$ & $34,324,110.0$ & $35,420,320.0$ \\
\hline Malta & $6,599.5$ & $6,836.2$ & $7,160.6$ & $7,638.5$ & $8,449.1$ & $9,266.1$ & $9,926.6$ \\
\hline Netherlands & $631,512.0$ & $642,929.0$ & $645,164.0$ & $652,748.0$ & $663,008.0$ & $683,457.0$ & $702,641.0$ \\
\hline Austria & $295,896.6$ & $310,128.7$ & $318,653.0$ & $323,910.2$ & $333,062.6$ & $344,493.2$ & $353,296.9$ \\
\hline Poland & $1,445,298.0$ & $1,566,824.0$ & $1,629,425.0$ & $1,656,895.0$ & $1,719,769.0$ & $1,799,392.0$ & $1,858,637.0$ \\
\hline Portugal & $179,929.8$ & $176,166.6$ & $168,398.0$ & $170,269.3$ & $173,079.1$ & $179,809.1$ & $185,179.5$ \\
\hline Romania & $529,623.5$ & $562,062.4$ & $595,367.3$ & $637,456.0$ & $668,143.6$ & $712,658.5$ & $762,341.8$ \\
\hline Slovenia & $36,252.4$ & $36,896.3$ & $36,076.1$ & $36,239.2$ & $37,614.9$ & $38,836.6$ & $40,418.1$ \\
\hline Slovakia & $67,577.3$ & $70,627.2$ & $72,703.5$ & $74,169.9$ & $76,087.8$ & $78,896.4$ & $81,154.0$ \\
\hline Finland & $187,100.0$ & $196,869.0$ & $199,793.0$ & $203,338.0$ & $205,474.0$ & $209,604.0$ & $215,773.0$ \\
\hline Sweden & $3,519,994.0$ & $3,656,577.0$ & $3,684,800.0$ & $3,769,909.0$ & $3,936,840.0$ & $4,199,860.0$ & $4,404,802.0$ \\
\hline United Kingdom & $1,579,877.0$ & $1,635,062.0$ & $1,685,225.0$ & $1,752,554$ & $1,837,062.0$ & $1,888,737.0$ & $1,963,311.0$ \\
\hline Montenegro & $3,125.1$ & $3,264.8$ & $3,181.5$ & $3,362.5$ & $3,457.9$ & $3,624.7$ & \\
\hline Serbia & $3,067,210.2$ & $3,407,563.2$ & $3,584,235.8$ & $3,876,403.4$ & $3,908,469.6$ & $4,043,467.8$ & $4,261,927.5$ \\
\hline Bosnia and Herzegovina & $25,365.0$ & $26,231.3$ & $26,222.7$ & $26,778.8$ & $27,358.7$ & $28,585.8$ & $29,899.1$ \\
\hline $\begin{array}{r}\text { Former Yugoslav Republic } \\
\text { of Macedonia, the }\end{array}$ & $437,295.5$ & $464,186.3$ & $466,702.7$ & $501,891.0$ & $527,631.0$ & $558,953.6$ & $598,881.3$ \\
\hline Albania & $1,239,644.6$ & $1,300,624.1$ & $1,332,811.0$ & $1,350,052.6$ & $1,395,304.6$ & $1,427,799.0$ & $1,472,791.1$ \\
\hline Turkey & $1,160,014.0$ & $1,394,477.2$ & $1,569,672.1$ & $1,809,713.1$ & $2,044,465.9$ & $2,338,647.5$ & $2,608,525.7$ \\
\hline
\end{tabular}


Tabel 2 Real GDP growth in the EU, 2010-2016 (\% change compared with the previous year; \% per annum) (Eurostat 2017, Autor 2018)

Real GDP growth in the EU, 2010-2016, in \% per annum (E urostat 2017, Autor 2018)

\begin{tabular}{|c|c|c|c|c|c|c|c|c|c|}
\hline \multirow{3}{*}{ GeolTime } & & & & & & & & & \\
\hline & & 2010 & 2011 & 2012 & 2013 & 2014 & 2015 & 2016 & Average \\
\hline & & & & & & & & & $2010-2016$ \\
\hline \multicolumn{2}{|c|}{ EU (28 countries) } & 2.1 & 1.7 & -0.5 & 0.2 & 1.6 & 2.2 & 2.5 & 1.40 \\
\hline \multicolumn{2}{|c|}{ E uro area (19 countric } & 2.1 & 1.5 & -0.9 & -0.3 & 1.2 & 2.0 & 2.1 & 1.10 \\
\hline Belgium & & 2.7 & 1.8 & 0.1 & -0.1 & 1.6 & 1.5 & 1.2 & 1.26 \\
\hline Bulgaria & & 1.3 & 1.9 & 0.0 & 0.9 & 1.3 & 3.6 & 2.4 & 1.63 \\
\hline \multicolumn{2}{|c|}{ Czech Republic } & 2.3 & 2.0 & -0.8 & -0.5 & 2.7 & 4.5 & 3.4 & 1.94 \\
\hline Denmark & & 1.9 & 1.3 & 0.2 & 0.9 & 1.7 & 1.6 & 1.3 & 1.27 \\
\hline Gem any & & 4.1 & 3.7 & 0.5 & 0.5 & 1.6 & 1.7 & 1.9 & 2.00 \\
\hline Estonia & & 2.3 & 7.6 & 4.3 & 1.4 & 2.8 & 1.4 & 1.6 & 3.06 \\
\hline Ireland & & 2.00 & 0.00 & -1.10 & 1.10 & 8.50 & 26.30 & 5.20 & 6.00 \\
\hline Greece & & -5.5 & -9.1 & -7.3 & -3.2 & 0.4 & -0.2 & 0.0 & -3.56 \\
\hline Spain & & 0.0 & -1.0 & -2.3 & -1.7 & 1.4 & 3.2 & 3.2 & 0.40 \\
\hline France & & 2.00 & 2.10 & 0.20 & 0.60 & 0.90 & 1.10 & 1.20 & 1.16 \\
\hline Croatia & & -1.70 & -0.30 & -2.20 & -1.10 & -0.50 & 1.60 & 2.90 & -0.19 \\
\hline Italy & & 1.70 & 0.60 & -2.80 & -1.70 & 0.10 & 0.80 & 0.90 & -0.06 \\
\hline Cyprus & & 1.3 & 0.3 & -3.2 & -0.6 & -1.5 & 1.7 & 2.8 & 0.11 \\
\hline Latva & & -3.8 & 6.4 & 4.0 & 2.6 & 2.1 & 2.7 & 2.0 & 2.29 \\
\hline Lithuania & & 1.6 & 6.0 & 3.8 & 3.5 & 3.5 & 1.8 & 2.3 & 3.21 \\
\hline \multicolumn{2}{|c|}{ Luxem bourg } & 4.9 & 2.5 & -0.4 & 4.0 & 5.6 & 4.0 & 4.2 & 3.54 \\
\hline Hungary & & 0.7 & 1.7 & -1.6 & 2.1 & 4.0 & 3.1 & 2.0 & 1.71 \\
\hline Malta & & 3.5 & 1.4 & 2.6 & 4.5 & 8.3 & 7.4 & 5.0 & 4.67 \\
\hline \multicolumn{2}{|c|}{ Netherlands } & 1.4 & 1.7 & -1.1 & -0.2 & 1.4 & 2.0 & 2.2 & 1.06 \\
\hline Austria & & 1.9 & 2.8 & 0.7 & 0.1 & 0.6 & 1.0 & 1.5 & 1.23 \\
\hline P oland & & 3.6 & 5.0 & 1.6 & 1.4 & 3.3 & 3.8 & 2.7 & 3.06 \\
\hline Portugal & & 1.9 & -1.8 & -4.0 & -1.1 & 0.9 & 1.6 & 1.4 & -0.16 \\
\hline Rom ania & & -0.8 & 1.1 & 0.6 & 3.5 & 3.1 & 3.9 & 4.8 & 2.31 \\
\hline Slovenia & & 1.2 & 0.6 & -2.7 & -1.1 & 3.1 & 2.3 & 2.5 & 0.84 \\
\hline Slovakia & & 5.0 & 2.8 & 1.7 & 1.5 & 2.6 & 3.8 & 3.3 & 2.96 \\
\hline Finland & & 3.0 & 2.6 & -1.4 & -0.8 & -0.6 & 0.3 & 1.4 & 0.64 \\
\hline Sweden & & 6.0 & 2.7 & -0.3 & 1.2 & 2.6 & 4.1 & 3.2 & 2.79 \\
\hline \multicolumn{2}{|c|}{ United Kingdom } & 1.9 & 1.5 & 1.3 & 1.9 & 3.1 & 2.2 & 1.8 & 1.96 \\
\hline & & & & & & & & & \\
\hline Iceland & & -3.6 & 2.0 & 1.2 & 4.4 & 1.9 & 4.1 & 7.2 & 2.46 \\
\hline Norway & & 0.6 & 1.0 & 2.7 & 1.0 & 1.9 & 1.6 & 1.0 & 1.40 \\
\hline \multicolumn{2}{|c|}{ Switzerland } & 3.0 & 1.8 & 1.0 & 1.8 & 2.0 & 0.8 & & 1.73 \\
\hline & & & & & & & & & \\
\hline \multicolumn{2}{|c|}{ Montenegro } & & & -2.7 & 3.5 & 1.8 & 3.4 & & 1.50 \\
\hline \multicolumn{2}{|c|}{ Former Yugoslav Rep } & 3.4 & 2.3 & -0.5 & 2.9 & 3.6 & 3.8 & 2.4 & 2.56 \\
\hline Albania & & 3.7 & 2.4 & 1.4 & 1.0 & 1.8 & 2.6 & & 2.15 \\
\hline Serbia & & 0.6 & 1.5 & -1.0 & 2.6 & -1.8 & 0.8 & 2.8 & 0.79 \\
\hline Turkey & & 8.5 & 11.1 & 4.8 & 8.5 & 5.2 & 6.1 & & 7.37 \\
\hline \multicolumn{2}{|c|}{ China (including Hong } & 10.6 & 9.5 & 7.9 & 7.8 & 7.3 & 6.9 & 8.3 & 8.33 \\
\hline Yapan & & 4.2 & -0.1 & 1.5 & 2.0 & 0.3 & 1.2 & 1.0 & 1.44 \\
\hline \multicolumn{2}{|c|}{ United States } & 2.5 & 1.6 & 2.2 & 1.7 & 2.4 & 2.6 & 1.6 & 2.09 \\
\hline & & & & & & & & & \\
\hline \multicolumn{2}{|c|}{ Source of Data: } & & & & Eurostat & & & & \\
\hline \multicolumn{2}{|c|}{ Last update: } & & & & 14.02 .2018 & & & & \\
\hline \multicolumn{2}{|c|}{ Date of extraction: } & & & & $01 \mathrm{M}$ ar 2018 & $14: 17: 31$ & & & \\
\hline \multicolumn{2}{|c|}{ Hyperlink to the table: } & & & & \multicolumn{5}{|c|}{ http://ec.europa.eu/euros tat $/ \mathrm{tgm} / \mathrm{table}$. do?tab=table $\&$ in it } \\
\hline
\end{tabular}

Within the EU, real GDP growth varied considerably, both over time and among EU Member States (see Table 1). After a contraction in all of the Member States except Poland in 2009, economic growth resumed in 23 of the Member States in 2010, a situation that was repeated in 2011. However, in 2012 this development was reversed, as just fewer than half (13) of the Member States reported economic expansion. In 2013, the majority of Member States again recorded growth, with the number recording a positive rate of change reaching 17 in 2013 and rising to 25 in 2014 and 27 in 
2015; the one Member State with a negative rate of change in 2015 was Greece which recorded a fall of $0.2 \%$ after growth of $0.4 \%$ in 2014 and five successive reductions in economic output during the period from 2010 to 2013. In 2016, for the first time since 2010, none of the Member States reported a fall in GDP, with 27 reporting growth and Greece recording no change.

The highest growth rates in 2016 were recorded in Ireland (5.2 \%) and Malta (5.0 \%), while the lowest rates - apart from the $0.0 \%$ rate of change in Greece - were growth of $0.9 \%$ in Italy and $1.2 \%$ in France and Belgium.

Poland recorded positive rates of change throughout the period shown in Table 1, while Denmark, Germany, Estonia, France, Lithuania, Malta, Austria, Slovakia and the United Kingdom recorded their seventh consecutive positive annual rate of change in 2016; in other words their last negative annual rate of change was at the height of the crisis in 2009.

The effects of the global financial and economic crisis lowered the overall performance of the EU Member State economies when analyzed during the last decade. The average growth rates of the EU-28 and the euro area (EA-19) between 2010 and 2016 were 1,40\% per annum and 1,10\% per annum respectively (see Table 2). The highest growth, by this measure, between 2010 and 2016 was recorded for Ireland (average growth of $6,00 \%$ per annum), followed by Malta (4,67 \%), Poland $3.06 \%$ ) and Slovakia (2,96 \%). By contrast, the overall development of real GDP during the period from 2010 to 2016 in Greece, Italy, Croatia and Portugal was negative.

Figure 1 Real GDP growth, 2010-2016 (\% change compared with the previous year) (Eurostat 2017, Autor 18))

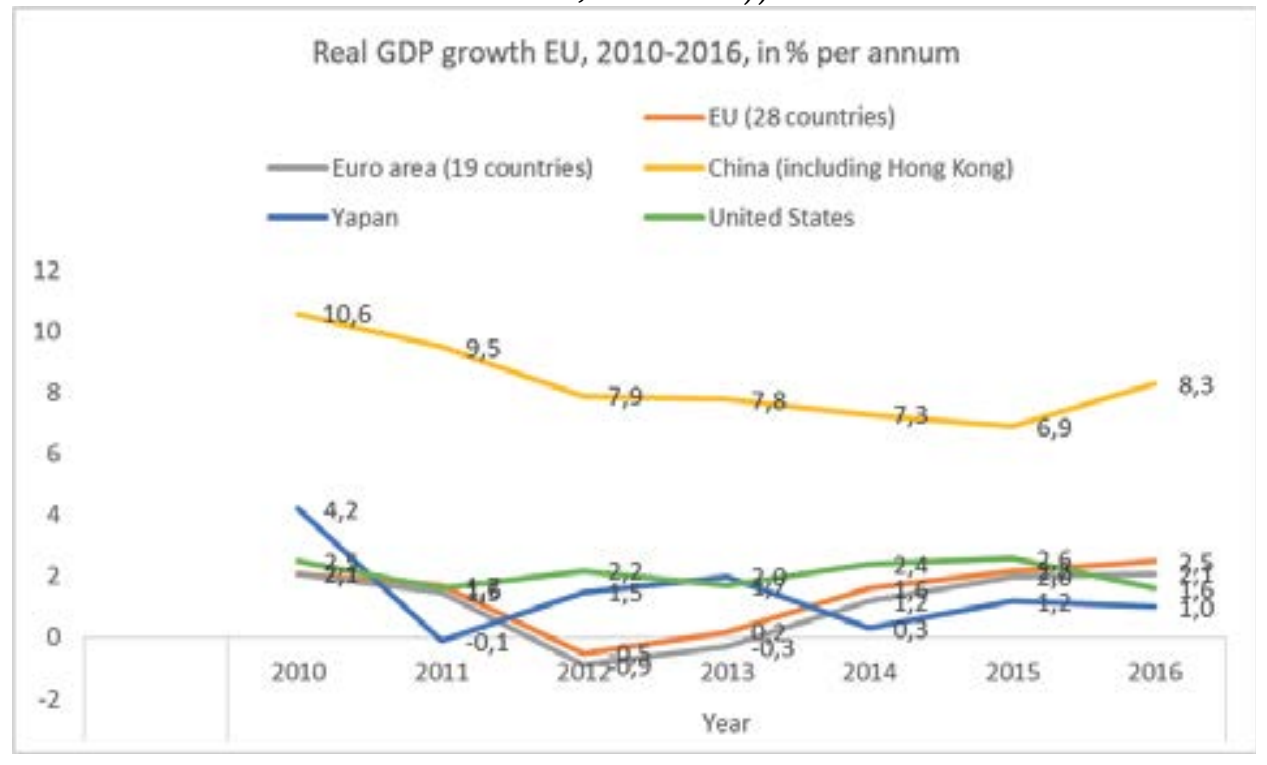

The global financial and economic crisis resulted in a severe recession in the EU, Japan and the United States in 2009 (see Figure 1), followed by a recovery in 2010. The crisis was already apparent in 2008 when there had been a considerable reduction in the rate of increase for GDP in the EU28 and this was followed by a fall in real GDP of $4.4 \%$ in 2009. The recovery in the EU-28 saw the volume index of GDP (based on chain linked volumes) increase by $2.1 \%$ in 2010 and there was a further gain of $1.7 \%$ in 2011. Subsequently, GDP contracted $0.5 \%$ in 2012 in real terms, before progressively larger positive rates of change were recorded in $2013(0.2 \%), 2014$ (1.6\%) and 2015 $(2.2 \%)$. In the euro area (EA-19) the corresponding rates of change were very similar to those in the EU-28 through to 2010, while the growth recorded in 2011 was slightly weaker $(1.5 \%)$ and the contraction in 2012 was stronger (-0.9\%) and was sustained into $2013(-0.3 \%)$. In 2014 and 2015, real GDP growth in the euro area was somewhat weaker than that in the EU-28 as a whole. 
The subject of our interest are flows of foreign direct investment and their impact on the changes of gross domestic product, as an important macroeconomic indicator. The share of investments at current market prices in GDP in 2005, 2010 and 2015 is shown in Table 3 for the EU zone.

Table 3 Investment at current market prices, 2005, 2010 and 2015 (\% share of GDP)

(Eurostat 2018, Autor 2018)

\begin{tabular}{|c|c|c|c|c|c|c|c|c|c|c|c|c|}
\hline \multicolumn{13}{|c|}{ Investment at current market prices, 2005, 2010 and 2015 (\% share of GDP) (Eurostat 2018) } \\
\hline & \multicolumn{3}{|c|}{ Total investment } & \multicolumn{3}{|c|}{ Public investment } & \multicolumn{3}{|c|}{ Business investment } & \multicolumn{3}{|c|}{ Household investment } \\
\hline GeolTime & 2005 & 2010 & 2015 & 2005 & 2010 & 2015 & 2005 & 2010 & 2015 & 2005 & 2010 & 2015 \\
\hline EU ( 28 countries) & 21,9 & 20,4 & 19,9 & 3,2 & 3,5 & 2,9 & 12,2 & 11,3 & 12,0 & 6,5 & 5,6 & 5,0 \\
\hline Euro area (EA-19) & 22,4 & 20,9 & 20,0 & 3,1 & 3,4 & 2,7 & 12,2 & 11,5 & 12,0 & 7,0 & 6,0 & 5,2 \\
\hline Ireland & 29,5 & 14,0 & 19,0 & 3,8 & 3,3 & 2,9 & 20,2 & 8,5 & 11,3 & 5,6 & 2,2 & 2,9 \\
\hline Norway & 20,3 & 20,6 & 23,4 & 3,4 & 4,1 & 4,9 & 11,8 & 11,9 & 12,6 & 5,1 & 4,5 & 5,9 \\
\hline Switzerland & 24,5 & 22,8 & 23,9 & 3,0 & 3,1 & 3,0 & 16,5 & 15,4 & 16,9 & 5,0 & 4,4 & 4,1 \\
\hline Serbia & 20,1 & 18,6 & 17,2 & & & & & & & & & \\
\hline
\end{tabular}

The vast majority of investment was made by the private sector, as can be seen from Table 3. In 2015, investment by businesses and households accounted for $17.0 \%$ of the EU-28's GDP, whereas the equivalent figure for public sector investment was $2.9 \%$. Investment by the business sector was highest in Switzerland (16.9 \%) and Norway (12,6\%). Investment by households (as a share of GDP) in 2015 was notably lower than in 2005 in EU (28 countries), Euro area (EA-19), Ireland and Switzerland, while it higher in Norway.

Table 4 presents the inflows and outflows of foreign direct investment in the period from 2004 to 2015, and data for the first quarter of 2016 for the EU, and the total FDI stock per year of the observed period (OECD 2016 ).

Table 4 FDI flows in millions of euros for EU (Eurostat 2017, European Union, OECD Foreign Direct Investment Statistics, https://knoema.com/OECDFDIS2017/oecd-foreign-directinvestment-statistics (OECD 2017 ).

\begin{tabular}{|c|c|c|c|c|}
\hline \multirow{3}{*}{ YEAR } & $\begin{array}{c}\text { Foreign Direct } \\
\text { Investment (FDI) }\end{array}$ & $\begin{array}{c}\text { Foreign Direct } \\
\text { Investment (FDI) }\end{array}$ & \multicolumn{2}{|c|}{ Stock (total value) FDI } \\
\hline & Inflows & Outflows & Inflow FDI & Outflow FDI \\
\hline & EUR milions & EUR milions & EUR milions & EUR milions \\
\hline 2004 & 244.179 & 369.134 & $4.846,365$ & $5.420,856$ \\
\hline 2005 & 591.234 & 669.041 & $5.690,696$ & $6.305,140$ \\
\hline 2006 & 726.462 & 879.818 & $5.946,830$ & $6.546,792$ \\
\hline 2007 & 1.065 .473 & 1.278 .121 & $7.536,334$ & $8.138,913$ \\
\hline 2008 & 582.517 & 919.366 & $6.976,821$ & $8.200,076$ \\
\hline 2009 & 512.626 & 612.534 & $7.644,430$ & $9.589,730$ \\
\hline 2010 & 480.892 & 585.530 & $7.596,391$ & $9.111,480$ \\
\hline 2011 & 652.062 & 725.924 & $7.716,407$ & $9.370,997$ \\
\hline 2012 & 345.096 & 392.379 & $8.223,772$ & $9.716,007$ \\
\hline 2013 & 315.559 & 333,559 & $8.789,142$ & $10.397,848$ \\
\hline 2014 & 264.794 & 226.858 & & \\
\hline 2015 & 494.272 & 508.522 & & \\
\hline 2016 & $705.255^{*}$ & $612.180 *$ & & \\
\hline 2016 Q1 & 235.085 & 204.060 & & \\
\hline
\end{tabular}


Figure 2 FDI inflow and outflow in EU (Author 2018)

\section{FDI FLOWS IN MILLIONS OFEUROS FOR EU-28}

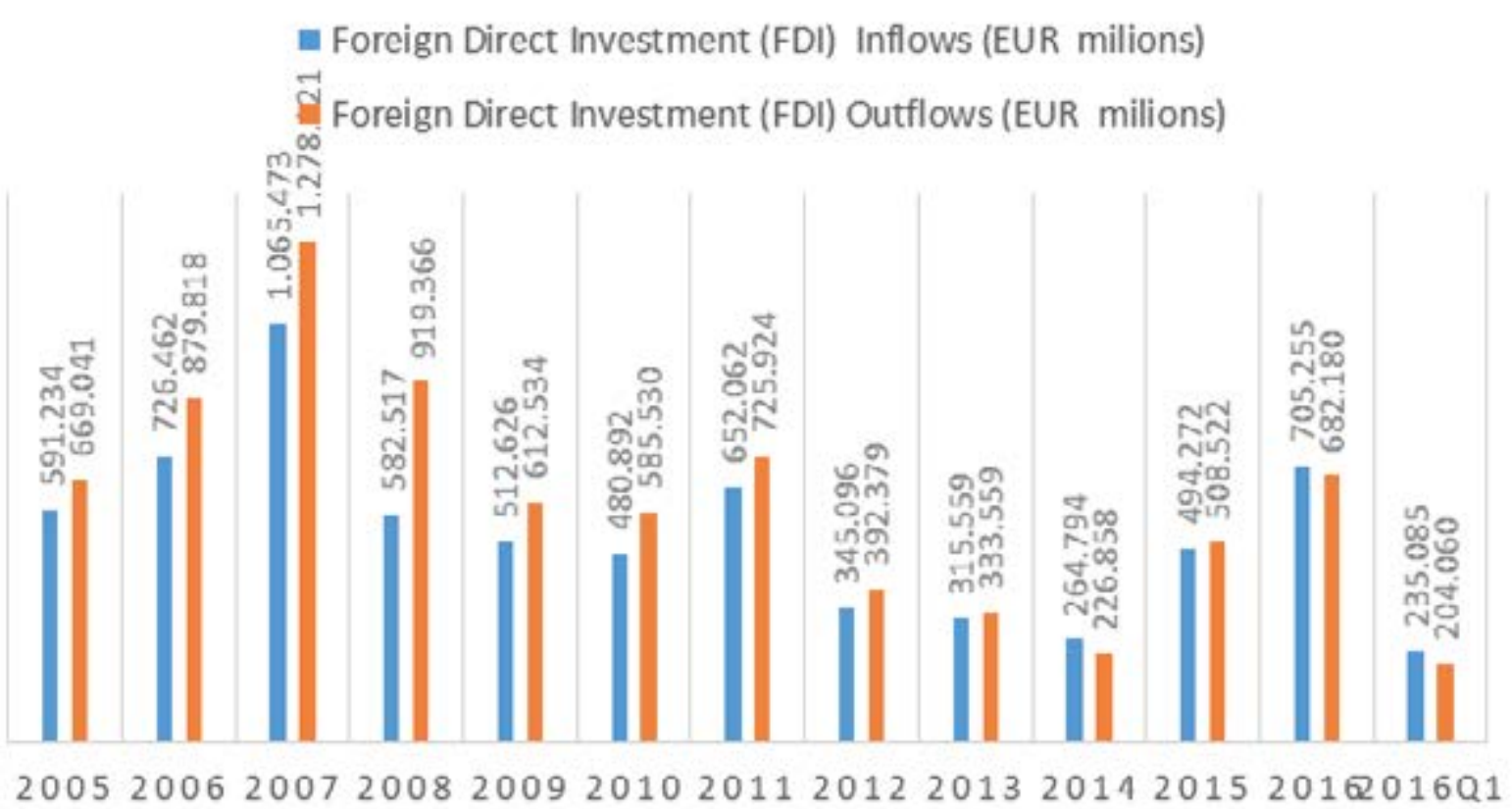

From Table 4 and the Figure 2, it can be seen, that inflows and outflows of foreign direct investment in the initial years of the period from 2005 to 2007, recorded a steadily increase. If, we take year 2005 as the base year, then the outflow of foreign direct investment in 2006 grew enormously, from 669,041 million to 879,818 million euros, while the inflow increased from 591,234 million to 726,462 euros, i.e. over 22,87\%. The upward trend continued until the end of 2007. During 2008, a decline in flows, in the inflow and outflow, of foreign direct investment was recorded due to the global crisis.

Therefore, the crisis which was present at global financial markets has the reflection on the economy of the Union. Being caused by mismatch of financial and real sectors of the economy, its effects were manifested in the decline in aggregate demand, slowing growth, deflation and rising unemployment. Regardless of the contagion of the crisis from the US financial markets, the European Union still has a close relationship with the US as the largest foreign trade partner, with which it has realized huge traffic of goods, services and capital. On a daily basis, it is significantly higher than one billion euros. Likewise, the EU is continuously making efforts to: increase participation in world trade, achieve the growth of all forms of investment and innovation, and to make upgrade in entrepreneurship skills and to improve corporate social responsibility level.

It is indisputable that the EU countries, same as the most of the world economy, reduced investment activity during the financial crisis, especially outside its borders. Among others, by these measures they try to reduce the negative effects of the global economic crisis. Negative trend and big drop in foreign direct investment continued in 2009, in which the crisis escalated. Many of the world economies were temporarily closed because of concerns for internal economic situation. Similarly, in 2010 negative inflows and outflows of foreign direct investment were recorded.

Since 2007, for the first time in 2011, the EU 27 has noticed the recovery and growth of foreign direct investment. The growth was negligible and did not recover the overall level of investment, bearing in mind that foreign direct investment in 2007 was significantly higher, on the both sides, in inflows and outflows. In 2012, again the decrease of FDI flow was recorded in comparison to the previous year, due to the second wave of the global crisis and the specific financial and fiscal crisis, which includes the individual EU member states, especially Greece.

Flow of foreign direct investment vary each year and it has an increase in periods of growth, and 
decrease in periods of recession. In the European Union, after a drop of 55\% in 2008, foreign direct investment recovered in 2009 and then in the following years they continued to fall until 2011 (Eurostat, 2016).

Unlike foreign direct investment flow, which fluctuates over the year, the total stock of FDI per year is not decreased, but is constantly growing. That fact shows that EU countries are attractive for foreign investment.

\section{INVESTIGATION OF THE IMPACT OF FOREIGN DIRECT INVESTMENT ON ECONOMIC DEVELOPMENT IN BOSNIA AND HERZEGOVINA}

Bosnia and Herzegovina (BH) has set its FDI policies in the context of liberalization of the market, foreign trade and capital movements, combined with the privatization of state capital in the economy as the most important channel for attracting FDI. In the post-war conditions of economic recovery and transition in $\mathrm{BH}$, the economy transition in the conditions of the Dayton Constitution, which gave the central state very limited powers, was to be restored in a very short period of time, and transferred the key development responsibilities to the entities and, in part, to the cantons in the Federation of BH.

Since FDIs are private-led investments based on a profit motive with varying variations and goals that drive them, their direction towards the country's development goals required, with the liberalization of the market and the overall economy, parallel creation of an incentive macroeconomic and business environment and the development of institutions capable of create and implement consistent macroeconomic, development and sectoral policies.

The current state of FDI in BH is reflected in the low volume and unfavorable structure of FDI, which have mostly entered the country through privatization. With its weakening, the FDI inflow is based on symbolic values, so the marginal effects of FDI decline, especially in the period after the global crisis hit the country.

The expected contribution of this paper is to initiate a new way of looking at the role of FDI in the development of $\mathrm{BH}$ and a new way to approach the creation of FDI public policies, in particular the FDI promotion policy. In essence, it is an attempt to point out the limited results in attracting FDI in $\mathrm{BH}$ in the conditions of weak state institutions and the exclusive functioning of market forces as the basis for neo-liberal access to the economy.

\section{THEORETICAL AND EMPIRICAL ASPECTS OF FDI WHICH ONE IMPORTANT FOR FDI PROMOTION POLICY}

Foreign direct investment (FDI) is defined as long-term interest based investments that reflect a lasting interest and control by a domestic resident of an economy in a company resident in another economy (OECD, 1996, in: WIR; 2007, 245). According to the International Monetary Fund (IMF), FDIs consist of the founding equity, reinvested profits and intra-corporate loans (WIR; 2007, 245246). Transnational companies (TNCs) are companies that have a parent company and subsidiaries (subsidiaries) in their structure, with ownership over $10 \%$ in subsidiaries and in subsidiaries above 50\% (WIR, 2007, 245 ). Although in many definitions it is pointed out that the TNCs are big powerful global companies, in our opinion, the growing FDI of medium and small companies around the world, including the emergence of born global companies, is seeking a redefinition of the term TNC. Therefore, in this work under the TNC, we will to mark all companies that make FDI, and in their structure there are global, regional or multinational companies, but according to their marketing focus.

Among the many theories of internationalization of production and FDI, we highlight the OLI theory as an acceptable form of explaining the aspects of FDI relevant to the FDI policy. The OLI theory of Dunning $(1977,1979,2000)$ is based on the eclectic paradigm of foreign investments. 
This theory explains FDI by three groups of factors: 1) the advantages of ownership over certain knowledge (human resources, R \& D, know-how), tangible (equipment, capital, infrastructure) and intangible (patents, brands, licenses), or in the form of market competitive advantages; 2) location advantages relate to those location factors that facilitate the economic valorization of competitive advantages of the company outside the borders of the country of origin, and 3) the advantages of internalization are to unify all international TNC activities within a unique business network managed by the TNC's top.

When it comes to location benefits, they are different depending on the type of FDI. According to the motives for their taking FDIs are divided into four groups: 1) market-oriented FDIs (market seeking FDIs), 2) resource-oriented FDIs (resource seeking FDIs), 3) efficiently-oriented FDIs (efficiently seeking FDI), and 4) strategically oriented FDIs (strategic FDIs). In the context of various types of FDIs, lokacion advantages are expressed through: 1) country-specific determinants, which influence the creation of the advantages of the TNC subsidiary, 2) industry-specific determinants, which can be distinguished by their influence from those at the country level, and 3) firm-specific determinants that express the competitive power of the TNC and its subsidiary in a particular country.

These specificities have their own expression in different types of FDI according to the mode of realization. Acquisitions are a way to take over a well-established company in the target market of the TNC. Greenfield FDIs are a choice in case of establishing a new and more efficient TNC activity. Acquisitions were the basic channel of FDI inflows into transition countries (Demirbag et al., 2008). Brownfield FDIs are the kind of investment that initially relies on acquisitions, and then enters a deep restructuring phase, where extensive investments are made that have the character of a greenfield FDI. Most of the acquisitions of former state-owned enterprises in transition countries that have been successfully restructured have actually gone through this type of investment (Meyer and Estrin, 2001, 576-577).

Countries in transition are attracted by FDIs by the action of attractive factorspulling action factors that reflect the attractiveness of the business environment and the impact of push factors that offer potential investors specific investment projects. Bosnia and Herzegovina has attracted most of its FDI based on push factors through the privatization process, but the removal of deposits in the FDI inflow is associated with the activation of pull factors arising from the business environment offered to potential investors (Domazet et 2008,118-124).

Most of the studies conducted on the impact of FDI on the economic development of FDI recipient countries show positive results. Mehić (2010) proves that, with the traditional determinants of FDI, the quality of institutions has a positive impact on the FDI earnings in the countries of Southeast Europe. It also proves that FDIs have a positive and significant impact on economic growth and employment, and that the presence of the TNC in the region contributes to the increase in both exports and imports of countries in the region. In contrast, Mencinger (2003) found that in the period 1994-2001. in eight countries of Central and Eastern Europe, the effects of FDI on the GDP movement were negative, creating negative effects on the current account. The explanation for this author is that FDIs are realized through acquisitions based on mass privatization. Domazet (2003) finds that the subsidiaries of foreign TNCs in $\mathrm{BiH}$ in 2002 had a predominantly market motivation, ie they were oriented to the domestic market, generating imports for the domestic market and creating negative spillover effects on the balance of payments.

In addition to the undeniable recommendations for the promotion of FDI, there are votes against FDI as a way of reducing the independence of countries and on an uneven basis, the influence of TNCs and countries of origin of FDI on the country of the recipient of FDI is strengthened. Jacobsen (2011) suggests that economic nationalism, especially in countries in transition, in addition to justified demands for the conduct of appropriate industrial policies for the development of domestic manufacturing companies, often means lobbying for the maintenance of unproductive domestic enterprises, finding the culprit for their loss of position in the emergence of foreign 
enterprises and openness of the domestic economy. The authors argue that economic nationalism can lead to the gains of individual groups, but that social development losses may be higher due to FDI resistance, especially in cases where it is an FDI-based export-oriented production offering employment potential.

Table 5. shows the state and flows of FDI in Bosnia and Herzegovina from 2007 to 2016 in millions of EUR.

Table 5 The states and flows of FDI in Bosnia and Herzegovina 2007-2016. (in millions of EUR), (Sources:CBBH Bulletin and Panorama Necto (http://statistics.cbbh.ba:4444/Panorama/ advanced_bs.htm)

\begin{tabular}{|c|c|c|c|c|c|c|c|c|c|c|c|c|}
\hline \multirow[t]{2}{*}{ Year } & \multicolumn{4}{|c|}{$\begin{array}{c}\text { State of FDI at the end of the year by } \\
\text { elements }\end{array}$} & \multicolumn{3}{|c|}{$\begin{array}{l}\text { Cash flow from income arising } \\
\text { from FDI }\end{array}$} & \multicolumn{5}{|c|}{ Annual increment of FDI by elements } \\
\hline & $\mathrm{E}+\mathrm{RD}$ & IK & $\mathrm{O}$ & Sum & ID & TD & Difference & E & $\mathrm{RD}$ & IK & $\mathrm{O}$ & Sum \\
\hline 2007 & 3.308 & 198 & 153 & 3.660 & 277 & 147 & 130 & 1.027 & 130 & 30 & 44 & 1.231 \\
\hline 2008 & 3.721 & 453 & 203 & 4.377 & 126 & 114 & 12 & 399 & 12 & 255 & 50 & 716 \\
\hline 2009 & 3.811 & 739 & 255 & 4.806 & -75 & 227 & -302 & 392 & -302 & 286 & 52 & 428 \\
\hline 2010 & 3.813 & 922 & 275 & 5.012 & 59 & 164 & -105 & 107 & -105 & 183 & 20 & 205 \\
\hline 2011 & 4.003 & 1.205 & 267 & 5.477 & 154 & 198 & -44 & 234 & -44 & 283 & -8 & 465 \\
\hline 2012 & 4.025 & 1.294 & 309 & 5.630 & 193 & 177 & 16 & 6 & 16 & 89 & 42 & 153 \\
\hline 2013 & 4.087 & 1.254 & 295 & 5.637 & 188 & 137 & 51 & 11 & 51 & -40 & -14 & 8 \\
\hline 2014 & 4.258 & 1.396 & 360 & 6.015 & 199 & 242 & -43 & 214 & -43 & 142 & 65 & 378 \\
\hline 2015 & 4.501 & 1.407 & 431 & 6.329 & 263 & 180 & 83 & 160 & 83 & 11 & 71 & 314 \\
\hline 2016 & 4.748 & 1.437 & 458 & 6.643 & 268 & 169 & 99 & 148 & 99 & 30 & 27 & 274 \\
\hline Total: & & & & & 1.652 & 1.755 & -103 & 2.698 & -103 & 1.269 & 349 & 4.213 \\
\hline
\end{tabular}

The situation and flows of FDI in Bosnia and Herzegovina 2007-2016. (in EUR million)

Note: Foreign Direct Investments (flows and stocks) are compiled in accordance with the most recent methodological standards and instructions of the International Monetary Fund (IMF) and Organization for Economic Cooperation and Development (OECD). Detailed methodological approach to compilation and dissemination of Direct Investments is presented in the IMF Balance of payments Manual, sixth edition and OECD Benchmark Definition of direct investments, forth edition. Implementation of new methodologies has resulted in changes as follows: - treatment of inter-company loans and other liabilities for financial intermediaries (transactions within this category, other capital, - withdrawals and repayments of debt - are excluded from Direct Investments, while these are included in category of Other Investments).

LEGEND: $\mathrm{E}=$ Founding stake (equity); $\mathrm{RD}=$ Reinvested earnings; $\mathrm{IK}=$ Intracompany loans; $\mathrm{O}=$ other; ID = Investment income (FDI profits); TD = Transferred profit

Foreign direct investment in $\mathrm{BiH}$ records a low level, a slow pace of growth and a deterioration in the investment structure. The cumulative value of FDI in BiH in 2016 was EUR 6,643 billion or $43.42 \%$ of the country's GDP. FDI per capita in the same year amounted to 2.494 EUR (CBBH, 2016). Compared with the FDI parameters of the countries in the neighborhood, which are not otherwise among the champions in attracting FDI, BiH lags behind Croatia (FDI 52.1\% of GDP, or 5.690 EUR pc), Montenegro (FDI 109.5\% of GDP ), Serbia (FDI 67.4\% of GDP and 3.342 EUR per pc) and Macedonia (FDI 45.3\% of GDP, or 2.010 EUR pc). 


\section{CHOICE OF VARIABLES, DATA AND METHODOLOGY}

Data include research for Bosnia and Herzegovina, which is available on an annual basis from 2007 to 2016 (Table 6.).

Table 6 Sample for research (CB BIH, Author 2018)

\begin{tabular}{|c|c|c|c|c|c|}
\hline Year & PFDI(\%BDP) & SR_BDPps & TRG (\%BDP) & Interest (Ks) & Rid_BDP \\
\hline 2007 & 11,83 & 12,41 & 90 & 11,65 & 0,21 \\
\hline 2008 & 5,37 & 13,18 & 92 & 11,65 & 0,25 \\
\hline 2009 & 1,4 & $-0,03$ & 72 & 9,41 & 0,25 \\
\hline 2010 & 2,4 & 2,31 & 82 & 8,85 & 0,27 \\
\hline 2011 & 2,7 & 3,48 & 91 & 8,89 & 0,19 \\
\hline 2012 & 2,3 & 0,05 & 88 & 7,68 & 0,22 \\
\hline 2013 & 1,5 & 2,24 & 88 & 7,63 & 0,25 \\
\hline 2014 & 3 & 2,31 & 91 & 6,67 & 0,29 \\
\hline 2015 & 2,1 & 4,73 & 87 & 5,62 & 0,32 \\
\hline 2016 & 1,8 & 4,79 & 84 & 5,45 & 0,33 \\
\hline
\end{tabular}

The relationship between foreign direct investment and its determinants is estimated by the following regression equation:

$$
\text { PFDI_BDPit }=\beta 0+\beta 1^{\star} \text { SR_BDP psit }+\beta 2^{\star} \text { TRG_BDPit }+\beta 3^{\star} \text { Rid_BDPit }+\beta 4^{\star} \text { Ksit }+ \text { e }
$$

where the variable is:

PFDI_BDPit, and represents the net inflow of foreign direct investment as a percentage of gross domestic product. This is the amount of fixed capital, reinvested profit, long-term capital and shortterm capital as shown in the balance of payments. This series shows net foreign FDIs by foreign investors and is divided by GDP. Independent variables are all the rest.

SR_BDPpsit denotes the growth rate of real GDP per capita, which is a proxy variable for market size and growth. According to the theory and previous research, the expected sign of a GDP growth rate per capita should be positive, as a larger and more developed market offers more opportunities to foreign investors.

TRG_BDPit denotes the share of trade in GDP, which is a proxy variable for the degree of openness calculated as a sum of exports and imports as a share in GDP. For investors it is very important that the country is open and that there are no trade restrictions. It is therefore expected that greater openness will attract more foreign direct investment.

Rid_BDPit represents R \& D expenditures as a percentage of GDP, which is a proxy variable for technology. Research and development is a good indicator of both technology and human capital. At the same time, research and development creates a new technology that reduces the technological gap to other countries. It is a signal to foreign investors that the host country has already reached the required level of human capital for the independent advancement of technology. It is believed that higher investment in research and development is attracting more foreign direct investment, as companies look for educated and high-quality workforce. However, opinions are divided.

Ks is the interest rate on borrowing money or loans. It includes short-term and mid-term financing needs of the private sector. This rate is normally different with the borrowers' creditworthiness and financing objectives. The terms and conditions attached to these rates vary by country. If interest rates on borrowed money are high in the country, a smaller inflow of foreign direct investment is expected, ie the negative sign of the coefficient with the variable Ks. 
Table 7 Display of selected variables, explanation and source (Author 2018)

\begin{tabular}{|l|l|c|c|}
\hline VARIABLE & \multicolumn{1}{|c|}{ DESCRIPTION } & SOURCE & $\begin{array}{c}\text { EXPECTED } \\
\text { PRESENT }\end{array}$ \\
\hline PFDI_BDP & $\begin{array}{l}\text { Net inflow of foreign direct investment expressed in } \\
\text { (\%) of GDP }\end{array}$ & CB BH & $\begin{array}{c}\text { Dependent } \\
\text { variable }\end{array}$ \\
\hline SR_BDPps & $\begin{array}{l}\text { Growth rate of real GDP per capita (proxy variable for } \\
\text { market size and growth) }\end{array}$ & CB BH & + \\
\hline TRG_BDP & Share of trade in GDP (proxy variable for openness) & $\mathrm{CB} \mathrm{BH}$ & + \\
\hline Ks & Interest rate on loans & $\mathrm{CB} \mathrm{BH}$ & - \\
\hline Rid_BDP & $\begin{array}{l}\text { R \& D expenditure as a percentage of GDP (proxy } \\
\text { variable for technology) }\end{array}$ & $\mathrm{CB} \mathrm{BH}$ & + \\
\hline
\end{tabular}

Table 7. summarizes the variables in the model and shows the expected sign of the coefficients based on the theoretical discussion. However, not all variables are discussed and included due to the unavailability of data. I also used the same data sources, bearing in mind the different methodologies when comparing databases of different institutions.

In accordance with the problem, the subject and objectives of the research, and the hypotheses set, the specific methodology of this research work has been developed as follows.

To prove basic research hypotheses that read:

H1: Market growth has a significant impact on FDI inflows.

H2: The country's openness has a significant impact on FDI inflows.

H3: Investing in R \& D has a significant impact on FDI inflows.

H4: Interest rate significantly influences FDI inflows.

The correlation analysis methods have preliminarily tested the existence of a connection in the movement of independent variables.

\section{RESEARCH RESULTS}

From Table 8. Descriptive statistics for the entire sample from 2007 to 2016 using the Statistic 10 programshows the number of observations for the selected variables, the average value of the selected variables and Standard Deviation (Author 2018).

Table 8 Descriptive statistics for the entire sample from 2007 to 2016 (Autor 2018)

\begin{tabular}{|l|c|c|c|c|c|}
\hline \multirow{2}{*}{ VARIABLE } & \multicolumn{5}{|c|}{ Descriptive statistics (Panel analysis data) } \\
\cline { 2 - 6 } & Valid N & Mean & Minimum & Maximum & Std.Dev. \\
\hline PFDI(\%BDP) & 10 & 3,440 & 1,400 & 11,830 & 3,156119 \\
\hline SR(BDPps) & 10 & 4,547 & $-0,030$ & 13,180 & 4,643861 \\
\hline TRG(\%BDP) & 10 & 86,50 & 72,00 & 92,00 & 6,0046 \\
\hline Interest (Ks) & 10 & 8,197 & 5,450 & 11,650 & 1,975028 \\
\hline Rid_BDP & 10 & 0,258 & 0,190 & 0,330 & 0,045656 \\
\hline
\end{tabular}

The average net FDI inflow is 3.44\% of GDP, in the observed period with an average deviation from the arithmetic mean of $3.156 \%$. The net inflow of foreign direct investment as a percentage of GDP ranges from $1.40 \%$ to $11.83 \%$.

The average GDP growth per capita is $4.547 \%$, in the observed period, with an average deviation from the arithmetic average of $4.6438 \%$. The minimum value of the growth rate of GDP per capita was $-0.030 \%$ and it refers to the growth rate in 2009 , while the maximum growth rate was $13.18 \%$, and it happened in 2016.

The share of trade in GDP on average is $86,5 \%$, which leads us to conclude that in the observed period the inflow of foreign direct investments was lower than the amount of GDP. The minimum 
value of this indicator is $72.00 \%$, and the maximum value is $92.00 \%$. The average deviation of the share of trade in GDP from the average is $6,046 \%$.

It can be concluded that $\mathrm{R} \& \mathrm{D}$ expenditures are not a high expenditure of GDP. Bosnia and Herzegovina invests only $0.258 \%$ of GDP in research and development. The minimum investment value in $\mathrm{R} \& \mathrm{D}$ is $0.19 \%$ in 2010 , while the maximum investment value is modest $0.33 \%$ of GDP in 2016.

The average interest rate on loans was $8.197 \%$, the minimum amount was $5.45 \%$, and the maximum was $11.65 \%$ in 2007. Namely, the Transition Process did not run smoothly, in 1996 there was a crisis in the banking sector that caused the currency crisis.

\section{CORRELATION ANALYSIS}

For the observed sample with the help of Statistics 10 programs, the author made a correlation matrix (Table 9.).

Table 9 Authors calculation with the help of Statistics 2010 programs (Author 2018)

\begin{tabular}{|l|c|c|c|c|c|c|}
\hline \multirow{2}{*}{ VARIABLE } & \multicolumn{7}{|c|}{ Correlation analysis } \\
\cline { 2 - 7 } & Std.Dev. & PFDI(\%BDP) & SR(BDPps) & TRG(\%BDP) & Interest (Ks) & Rid_BDP \\
\hline PFDI(\%BDP) & 3,156119 & 1,000000 & & & & \\
\hline SR(BDPps) & 4,643861 & 0,626143 & 1,000000 & & & \\
\hline TRG(\%BDP) & 0,060046 & $0,750014 *$ & 0,480125 & 1,000000 & & \\
\hline Interest (Ks) & 1,975028 & 0,474166 & 0,152439 & 0,299696 & 1,000000 & \\
\hline Rid_BDP & 0,045656 & $-0,349720$ & 0,098466 & $-0,407415$ & $-0,738493^{*}$ & 1,000000 \\
\hline
\end{tabular}

From the correlation matrix it can be noticed that there is no statistically significant, strong connection between any two variables, which makes it possible to conclude that it is justified to use all selected variables in model testing. All correlation coefficients of 0,80 or more would suggest that these variables should be omitted from the model. However, in this example we see that there is no problem of multicolarity between the selected variables.

The absolute value of the correlation coefficient (code: $r$ ) indicates the strength of linear relationships among variables. What is $\mathrm{r}$ closer to zero, the connection is weaker, and what is $\mathrm{r}$ closer to the number one, the connection is stronger. Person correlation coefficient is based on a comparison of the actual impact of observed variables to one another in relation to the maximum possible impact of two variables for the samples with a maximum of 30 elements.

Standardized measure of the strength of the statistical link between the phenomenon presented in two quantitative variables is the correlation coefficient (Sosic I 1988). Since it is an arranged phenomena, the data can be displayed in the coordinate system. A set of these points is called a scatter diagram (Yan, X Su, X G 2009) from which one can see the dependence between variables. The correlation between phenomena can be positive and negative (Fox J 2008). In case of a positive linear correlation, if one variable is increasing corresponding linear increase in other variables will appear as well. If negative correlation is complete, sign $r$ takes the value of -1 .

Based on the above, the first application of the single linear regression model in this study can be expressed as follows:

$\mathrm{GDP}=\mathrm{f}(\mathrm{FDI})$

GDP - dependent variable,

FDI - an independent variable.

Data of the Central Bank of Bosnia and Herzegovina are used in the application of the single linear regression, i.e.: $\mathrm{GDP}=\mathrm{f}(\mathrm{FDI})$. 
In Table 10. lists Foreign direct investment flows and GDP, in millions of EUR and FDI share in\% GDP.

Table 10 Required data for a unique linear regression model, in millions of EUROs (Central Bank of BH, 2017, Author 2018)

\begin{tabular}{|c|c|c|c|c|c|c|c|c|}
\hline YEAR & $\mathrm{Xi}(\mathrm{FDI})$ & $\begin{array}{l}\text { Growth } \\
(\% \text { FDI })\end{array}$ & Yi (GDP) & $\begin{array}{l}\text { Growth } \\
(\% \text { GDP) }\end{array}$ & $\begin{array}{l}\text { FDI share in } \\
\text { GDP }(\%)\end{array}$ & $\mathrm{XY}$ & $\mathrm{X}^{2}$ & $\mathrm{Y}^{2}$ \\
\hline 2009 & 180 & $-73,68$ & 12.700 & $-2,90$ & 1.4 & 2.286 .000 & 32.400 & 161.290 .000 \\
\hline 2010 & 307 & 70,56 & 13.000 & 2,36 & 2.4 & 3.991 .000 & 94.249 & 169.000 .000 \\
\hline 2011 & 357 & 16,29 & 13.400 & 3,07 & 2.7 & 4.783 .800 & 127.449 & 179.560 .000 \\
\hline 2012 & 307 & $-14,00$ & 13.400 & 0,00 & 2.3 & 4.113 .800 & 94.249 & 179.560 .000 \\
\hline 2013 & 208 & $-32,25$ & 13.700 & 2,24 & 1.5 & 2.849 .600 & 43.264 & 187.690 .000 \\
\hline 2014 & 415 & 99,52 & 14.000 & 2,19 & 3.0 & 5.810 .000 & 172.225 & 196.000 .000 \\
\hline 2015 & 314 & $-24,34$ & 14.600 & 4,29 & 2.1 & 4.584 .400 & 98.596 & 213.160 .000 \\
\hline 2016 & 274 & $-12,74$ & 15.300 & 4,79 & 1.8 & 4.192 .200 & 75.076 & 234.090 .000 \\
\hline $\begin{array}{l}2017 \\
\text { Q1-Q3 }\end{array}$ & 119 & - & 16.100 & - & - & - & - & - \\
\hline$\Sigma$ & 2.362 & - & 110.100 & - & - & 32.610 .800 & 737.508 & 1.520.350.000 \\
\hline
\end{tabular}

The diagram shows that a constant decline in foreign direct investment in Bosnia and Herzegovina was recorded in 2012,2013, 2015 and 2016. A slight change for the better was in 2014, but after that year the trend of further inflow of foreign capital continued.

Analyzing the regression line for the dependent variable (GDP) which is shown as follows:

$y=a+b x$

For this research function of GDP is:

$B D P=a+b x=12.999+2,586 \times F D I$

The coefficient of determination is calculated using the formula:

$R^{2}=\frac{a \sum y+b \sum x y-n \bar{y}^{2}}{\sum y^{2}-n \bar{y}^{2}}=\frac{12.999 \times 110.100+2,586 \times 32.610 .800-8 \times 13762,5^{2}}{1.520 .350 .000-8 \times 13762,5^{2}}=0,053$

Since the coefficient of determination is less than 1 , we can conclude that the points are scattered around the line $(\mathrm{y})$. That means that the higher the linear dependency is between $\mathrm{X}$ and $\mathrm{Y}$, if the coefficient of determinations closer to 1 , and vice versa.

The coefficient of correlation is calculated using the formula

$r=\sqrt{R^{2}}=\sqrt{0,053}=0,23$

The absolute value of the correlation coefficient $(r)$ indicates the strength of linear relationship between the variables. Value of $\mathrm{r}$ closer zero shows that the connection is weaker, and opposite, if closer to unit, the connection is stronger. The correlation in this research is positive, indicating that the linear increase in one variable corresponding to a linear increase in other variables.

Since the calculated correlation coefficient is 0.23 , we can conclude that there is a weak $\quad(0.20 \leq$ $\nabla \mathrm{r} \bigotimes<0.5 \mathrm{w}$ ) impact of independent variable (FDI) on the dependent variable (GDP). The linear regression shows that the increase in foreign direct investment in the fixed assets of 1 million euros, leads to an increase in GDP in value of 2,586 million euros. 


\section{CONCLUSION}

The foreign capital may affect economic development in three ways. First, it increases the domestic investment rates. To the extent that a country has a mismatch between savings and investment as a result of balance of payments deficit, the inflow of foreign capital can help boost investments in the country. Second, it increases business efficiency. The increase in productivity is resulting from the increase in efficiency, based on the transfer of experiences, new knowledge and new technologies that are brought in with foreign capital. Third, it stimulates the economic system and the business. The existence of efficient companies in the market can stimulate local competitors to innovate business in order to survive in the market. In this way, it increases the quality and diversity of local producers in a country that is the recipient of capital.

Acceleration of the economic development and the rapid pace of the development in Bosnia and Herzegovina is linked to the rate of accumulation. Accumulation is one of the main factors of development. The main problem of modern economic systems of developing countries is to ensure the mass and the rate of accumulation are sufficient to finance investments leading to economic development. The second goal is maximizing the efficiency of accumulation. The main issue of our country, which is preventing the development of the economy, is not that the economy is not able to produce, but that the fact that capital ends up in the hands of those social classes who use the capital in an unproductive manner.

Investments are a very important factor because they determine the speed of economic growth and development. There are other factors of the development such as: better and more efficient organization, better and more efficient use of production capacity, the higher level and quality of workforce education, on time application of new technologies and technical progress and so on. The basic criterion for determining the speed of development of the economic system is, apart from the increase in per capita income, is also the amount of investment together with other factors which are available means of achieving economic development for society as a whole.

Based on the survey results, the positive impact of foreign capital on economic development is proven by the statistical-quantitative analysis, where a positive correlation between FDI and GDP is recorded. Since the calculated correlation coefficient is 0.23 , we can conclude that there is a weak $(0.20 \leq|\mathrm{r}|<0.5)$ impact of FDI on the GDP. The linear regression shows that the increase in foreign direct investment in the fixed assets of 1 million euros, leads to an increase in GDP in value of 2,586 million euros.

However, a little correlation coefficient shows that foreign capital has an insignificant impact on the enabling and acceleration of the economic development in Bosnia and Herzegovina, but also that it is not the basic premise of the generation and acceleration of the economic development of Bosnia and Herzegovina. In addition, the economy of $\mathrm{BH}$ has no investment capacity, and must properly provide environment for the inflow of capital, which will be directed into those branches that will achieve the greatest benefit for the progress of the society as whole. 


\section{REFERENCES}

Todaro, M. P. \& Smit, S. C. (2006). Economic development, Sarajevo: TKD Sahinpasic Jovanovic \& Gavrilovic, P. (2006). International business finance. Belgrade: Faculty of Economics

Samuelson, P. \& Nordhaus, W. (1992) Economic growth in the long run the most important factor in the economic success of nations, McGraw-Hill

Dunning, J. (1982). „A Note on the Intra-industry Foreign Direct Investmen“. Banca Nazionale del Lavoro (Rome) March, p.p. 265-284

Popović, G. (2009). Economics of the European Union, the macroeconomic aspects and common policies. Banja Luka: Faculty of Economics

OECD (2016). Foreign Direct Investment for Development, Paris, Retrieved, February 14, 2018. https://knoema.com/OECDFDIS2017/oecd-foreign-direct-investment-statistics

Demirbag, M., Tatoglu, E., Glaister, K. W. (2008). Factors Affecting Perceptions of the Choice between Acquisition and Greenfield Entry: The Case of Western FDI in an Emerging Markets.

Domazet, A. et al. (2008). Analysis of reasons and causes of insufficient interest of domestic and foreign investors in the privatization process with the proposal of measures for improving the overall environment for investment through the privatization process in the FBiH, Sarajevo: Economic Institute.

Mehic, E. (2010), Determinants and Effects of Foreign Direct Investments in South Eastern Europe, Doctoral Dissertation, Sarajevo: Faculty of Economics.

Mencinger, J. (2003), Does Foreign Direct Investments Allways Enhance Economic Growth, Kyklos, Vol. 56 - 2003 - Fasc. 4, 491-508.

Jacobsen, J., Jacobsen, T. (2011). Economic nationalism and FDI The impact of public opinion on foreign direct investment in emerging markets, 1990-2005, Society and Business Review, Vol. 6 No. 1. Central Bank of Bosnia and Herzegovina. Bulletin and Panorama Necto, Retrieved, February 14, 2018 (http://statistics.cbbh.ba:4444/Panorama/advanced_bs.htm

Šošić, I, (1988). Problems in statistics. Zagreb: University of Zagreb, Faculty of Economics

Yan, X. Su, X. G. (2009) Linear Regression Analysis: Theory and Computing, World Scientific Publishing, New Jersey

Montgomery, D. C. Peck, E. A. Vining, G. G. (2012). Introduction to Linear Regression Analysis, 5th Edition, John Wiley \& Sons, New Jerse Central Bank of Bosnia and Herzegovina (2017) Foreign Direct Investments (DSU) - Balance and Performance. Retrieved, February 14, 2018.

http://www.fipa.gov.ba/informacije/statistike/investicije/

Eurostat (2017). Foreign direct investment statistics, Retrieved, February 16, 2018. http://ec.europa. eu/eurostat/statistics-explained/index.php/Foreign_direct_investment_statistics

Eurostat (2017).Investment at current market prices,2005,2010 and 2015 (\% share of GDP), Retrieved, February 16, 2018. http://ec.europa.eu/eurostat/statistics-explained/index.php 